\title{
Phytoliths as indicators of pedogenesis and paleoenvironmental changes in the Brazilian cerrado
}

\author{
Miriam Borba-Roschel ${ }^{\mathrm{a}, \mathrm{b}}$, Anne Alexandre ${ }^{\mathrm{b}, *}$, Angélica Fortes Drummond Chicarino \\ Varajão $^{\mathrm{a}}$, Jean Dominique Meunier ${ }^{\mathrm{b}}$, César Augusto Chicarino Varajão ${ }^{\mathrm{a}}$, Fabrice Colin ${ }^{\mathrm{c}}$ \\ ${ }^{a}$ DEGEO, Universidade Federal de Ouro Preto, Ouro Preto, Minas Gerais, 35400-000, Brazil \\ ${ }^{\mathrm{b}}$ CEREGE, Université d'Aix-Marseille III, Europôle Mediterranéen de l'Arbois, BP 80, 13545, Aix en Provence Cedex 4, France \\ ' IRD Noumea, BP A5, 98848, Nouvelle-Caledonie, France
}

Received 13 June 2005; accepted 19 August 2005

\begin{abstract}
This paper presents the preliminary results of phytolith analyses of a peat located in the cerrado of the Uberaba municipality, State of Minas Gerais, Brazil. The phytolith soil sequence is discussed by comparison with phytolith assemblages extracted from dominant plants (Cyperaceae and Poaceae). Increasing mean age of phytolith assemblages with depth is assumed. Poaceae Cuneiform bulliform cell, Parallelepiped bulliform cell and Elongate smooth long cell types dominate up to $80 \mathrm{~cm}$, rapidly drop to $42 \%$ at $80 \mathrm{~cm}$ and regularly decrease from $42 \%$ to $2 \%$ upwards. Cyperaceae Rondel concave type shows the inverse trend, being dominant in the upper part of the profile. This pattern can be assigned to increasing selective dissolution of the Cyperaceae phytolith type with depth, or/and to a decrease of water stress suffered by the grasses, leading to a decrease of bulliform cell silicification. Soil processes and paleo-environmental changes hypotheses are discussed.
\end{abstract}

(C) 2005 Elsevier B.V. All rights reserved.

Keywords: Phytolith; Cerrado; Poaceae; Cyperaceae; Brazil; Environmental change; Pedogenesis

\section{Introduction}

Absorbed in its soluble form by plant roots, silicon is incorporated into aerial tissue cells as micrometersized opal particles called phytoliths. These phytoliths are freed by degradation of the burlap organic matter and can be transferred to the soil or be dispersed in air or water (Bartoli and Wilding, 1980; Piperno, 1988; Alexandre et al., 1997). Because phytoliths are relatively stable in soils for thousands of years, they can give information on vegetation changes and pedogenic

\footnotetext{
* Corresponding author.

E-mail address: alexandre@cerege.fr (A. Alexandre).
}

processes during the Quaternary (e.g. Piperno and Becker, 1996; Fredlund and Tieszen, 1997; Alexandre et al., 1997; Delhon et al., 2003; Piperno and Jones, 2003).

Tropical peatlands represent repositories of $\mathrm{Si}$ and $\mathrm{Al}$, that, together with variable amounts of other elements, can provide the prime material for silicate neoformation during later diagenetic processes (Wüst and Bustin, 2003). Wüst and Bustin (2003) showed that in acid peat accumulating environments, most of silica neoformed minerals may originate from biogenic silica and especially phytoliths.

This study focuses on a peat profile of the Uberaba plateau (Minas Gerais-Brazil, 19 $23^{\prime} 91^{\prime \prime} \mathrm{S}$, $48^{\circ} 54^{\prime} 96 \mathrm{vW}$ ) covered by the cerrado. A preliminary 
${ }^{14} \mathrm{C}$ dating of the bulk organic matter shows that the base of the peat formed $27500 \pm 900$ years ago (Kirman et al., 2002). The present work gives a comparison between the sequence of phytolith assemblages extracted from the peat and phytolith assemblages extracted from the leaves of the main hydromorphic field plants. Preliminary hypothesis on phytolith dissolution and/or paleoenvironmental changes responsible of the phytolith sequence at the studied site, as well as consequences on pedogenesis are discussed.

\section{Material and methods}

The study area belongs to the cerrado biome, more specifically to the "earthmound fields", which are floodplain grasslands typical of Central Brazil. They are morphologically characterized by convex, rounded elevations scattered in a hydromorphic field. The climate of the region is defined as Köppen's Savanna Subtype (Aw), with rainy summers (NovemberMarch) and dry winters (May-September). The mean annual temperature is $22{ }^{\circ} \mathrm{C}$. The study area is located in a zone with an average annual rainfall of over 300 $\mathrm{mm}$. The Yellow-reddish (5YR 6/6 Munsell table) Latosol has developed on the Earthmounds and Humic Gleysol or peats has developed in hydromorphic areas.

Eleven samples at different depths (in m: JP 120130, JP 110-120, JP 100-110, JP 90-100, JP 80-90, JP 70-80, JP 50-60, JP 40-50, JP 30-40, JP 20-30, JP 10-20) of the peat profile were collected from an area of clay exploitation. The leaves of five samples of the dominant plants in the area were collected for analyses: Rynchospora emaciata (Cyperaceae), one Poaceae (undetermined species), Xyris sp. (Xyridaceae), Paepalanthus sp. (Eriocaulaceae) and Baccharis sp. (Asteraceae). Phytolith extraction followed Kelly's (1999) recommendations. For morphologic analysis under optical microscope, each extracted fraction was mounted in glycerol and Canada Balsam. Identification and taxonomic origin of the different types was based on the classifications of Twiss et al. (1969), Twiss (1992), Mulholland (1986), Mulholland and Rapp (1992), Fredlund and Tieszen (1994) and Bremond et al. (2005). Naming follows the International Code for Phytolith Nomenclature (ICPN Working Group et al., 2005).

For each section, more than 200 classified phytoliths with a diameter larger than $5 \mu \mathrm{m}$ were studied under S.E.M. and counted under optical microscope $(600 \times$ magnification). Classified phytoliths were divided into the following groups and their abundance is expressed in percentage of the sum of classified types:

(1) Cuneiform bulliform cell, parallelepiped bulliform cell, elongated smooth long cell types (40-200 $\mu \mathrm{m}$ in size) are produced by Poaceae (e.g. Kondo et al., 1994).

(2) Bilobate short cell, cylindrical polylobate, cross and acicular hair cell are produced by Poaceae (e.g. Mulholland, 1989).

(3) Papillae-type is produced by Cyperaceae (e.g. Wallis, 2003). Although the Rondel type is commonly attributed to Poaceae, we identified inside the leaf of the dominant Cyperaceae ( $R$. emaciata) a Rondel concave type which differs from the Poaceae Rondel type because significantly dorsally and ventrally more concave. This type is actually conical with oblong and concave ventral and dorsal faces.

(4) Globular granulate and cylindrical sulcate tracheid types are attributed to dicotyledons (Scurfield et al., 1974; Kondo et al., 1994; Stromberg, 2004).

(5) Globular echinate type is produced by Palmae (e.g. Kondo et al., 1994).

Phytoliths without identifiable shape were counted and labeled as non-classified phytoliths.

\section{Results and discussion}

\subsection{Phytolith assemblages extracted from leaves}

Phytolith types of the leaves of $R$. emaciata (Cyperaceae), which is the plant that covers ca. $90 \%$ of the hydromorphic field, are dominated by the Cyperaceae rondel concave type ( $96 \%$ of classified phytoliths). The papillae type accounts only for $2.5 \%$ and of the elongated smooth long cell type for $1.5 \%$ (Fig. 1).

The dominant Poaceae presents ca. $82 \%$ of the bilobate type; $14.1 \%$ of the Poaceae rondel type; $1.8 \%$ of the elongated smooth long cell type; $1.3 \%$ of the cuneiform bulliform cell type; $0.88 \%$ of the acicular hair cell type and $0.44 \%$ of the cylindrical polylobate type.

No classified phytoliths were found in the leaves of Xyris sp., Paepalanthus sp., and Baccharis sp.

\subsection{Phytolith assemblages from the peat}

Unclassified phytoliths increase regularly with depth (Fig. 2) as well as abundance of dissolution pits, especially on the cuneiform cell, parallelepiped bulliform cell and elongated smooth long cell types surfaces. This 


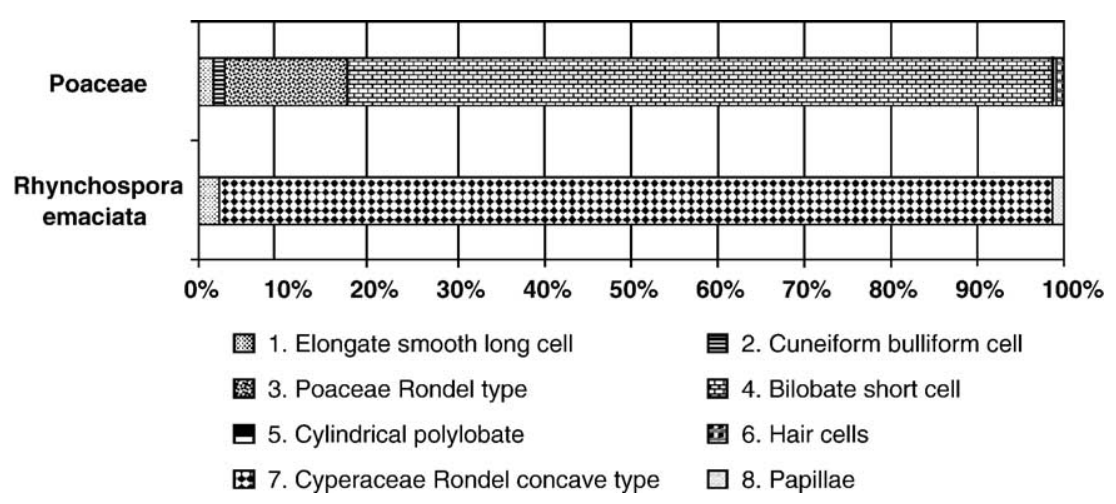

Fig. 1. Phytolith assemblages extracted from leaves of Poaceae (undetermined species) and Cyperaceae (Rhynchospora emaciata) from Uberaba plateau (MG, Brazil).

result indicates an increase of phytolith weathering with depth which also indicates an increase of their mean residence time (or mean age) with depth (e.g. Alexandre et al., 1999). Increasing mean age of phytolith assemblages with depth may be explained by two processes: (1) accumulation of organic layers slowly recycled and with high contents of phytoliths and (2) translocation of phytoliths from the top to the bottom of the profile, mainly due to bioturbation (Alexandre et al., 1997).

The globular echinate type occurs in a small amount at all levels (Fig. 3). Typical of the Palmae family, its occurrence in upper layers is in agreement with the current vegetation: the species Mauritia flexuosa (buriti) is the dominant species in the palm swamp that surround the hydromorphic field and a dwarf palm, Buthia leiospatha frequently occurs on the earthmounds.

The Globular granulate type, typical of ligneous dicotyledons also occurs in small amounts along the soil profile. Its occurrence in upper layers is linked to the earthmounds that are true habitat islands capable of bearing woody plants typical of the cerrado.
Despite the dominance of the species $R$. emaciata (Cyperaceae) in the study area, the Papillae type (characteristic of this family) can't be recovered from the soil. This type is subject to rapid dissolution and/or fragmentation (Alexandre et al., 1998).

Obvious trends in abundances of the dominant phytolith types from the bottom to the top of the humic horizon are displayed in Fig. 3: the fraction of Poaceae cuneiform bulliform cell, parallelepiped bulliform cell and elongated smooth long cell types is stable between $94 \%$ and $70 \%$ of the classified phytolith types below 80 $\mathrm{cm}$, rapidly drops to $42 \%$ at $80 \mathrm{~cm}$ and regularly decreases from $42 \%$ to $2 \%$ upwards. Inversely the Cyperaceae rondel concave type is stable between 5\% and $29 \%$ below $80 \mathrm{~cm}$, rapidly reaches $50 \%$ at $80 \mathrm{~cm}$ and regularly increases up to $94 \%$ upwards. The increasing trend of the Cyperaceae phytolith type can be assigned to an increasing selective dissolution of this type with depth or/and to a gradual vegetation change from a Poaceae-dominated cover to a Cyperaceae-dominated cover. However the lack of trend in the Poaceae

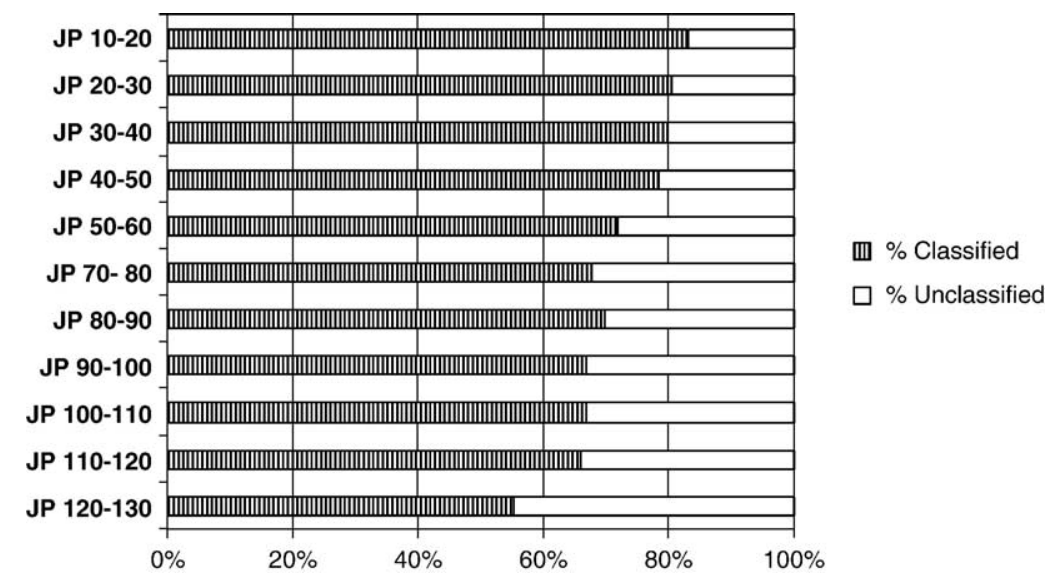

Fig. 2. Unclassified phytolith. Abundance in \% of the sum of counted phytoliths. 


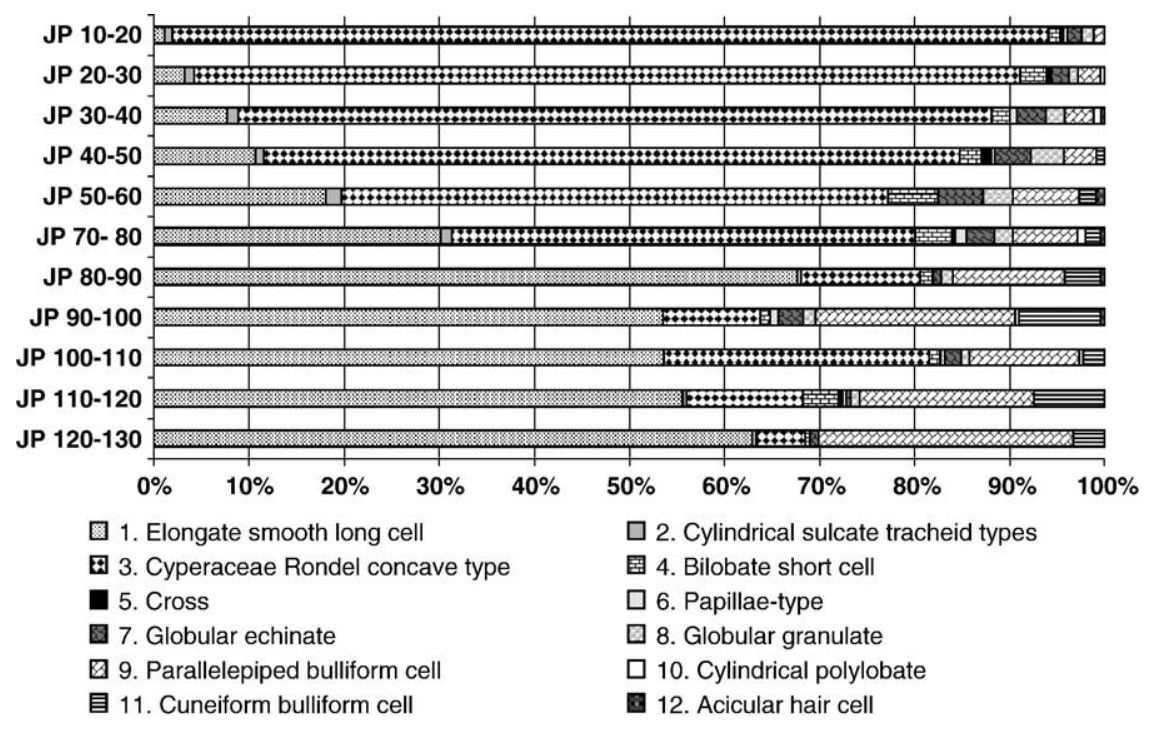

Fig. 3. Phytolith assemblages from the studied peat. Abundances in \% of counted classified types.

Polylobate type abundance argues against this second hypothesis.

Bremond et al. (2005) demonstrated that, for African grasslands, increasing silicification of the Poaceae bulliform cells is clearly linked to increasing water stress suffered by the Poaceae. Thus, following this idea, a third hypothesis for interpreting the phytolith sequence is that the dominance of Poaceae Cuneiform bulliform cell and Parallelepiped bulliform cell-types below $80 \mathrm{~cm}$ and their decrease upwards is related to the high water stress suffered by Poaceae in a first period (recorded up to $80 \mathrm{~cm}$ ), followed by the decrease of this water stress in a second period. Decreasing water stress may be related to a decrease of the amplitude of the soil hydration/dehydration successions.

\section{Conclusion-perspectives}

Comparing phytolith assemblages obtained from the modern dominating plants, and phytolith sequence obtained from the peat profile leads to the following indications: Cyperaceae dominating the current vegetation is today the main phytolith-producer. The related small phytolith type, dominant in the 80 upper $\mathrm{cm}$ may have been gradually dissolved with time leading to the dominance of bigger Poaceae types in the lower profile. This scenario would argue in favor of a significant flow of dissolved silica produced by phytoliths in the peat, and available for silicate neoformation as already suggested by Wüst and Bustin (2003) for a Malaysian peat. However, further investigations on phytolith concentra- tion and soil characteristics are needed to assess this hypothesis, which does not involve any paleo-environmental changes.

A second scenario involves a decrease of phytolith production due to a decrease in water stress suffered by grasses with time, which is to be linked to a decrease of the amplitude of the soil hydration/dehydration successions. This pattern may involve a change in soil hydromorphy associated to local or regional hydrological changes.

\section{Acknowledgments}

The authors thank CAPES/COFECUB and CNPq for financial support. We are grateful to Magnesita S.A. for the support given during the fieldwork.

\section{References}

Alexandre, A., Meunier, J.D., Colin, F., Koud, J.M., 1997. Plant impact on the biogeochemical cycle of silicon and related weathering problems. Geochim. Cosmochim. Acta 61 (3), 677-682.

Alexandre, A., Meunier, J.D., Lézine, A.M., Vincens, A., Schartz, D., 1998. Phytolith: indicators of grasslands dynamics during the late Holocene in intertropical Africa. Palaeogeogr. Palaeoclimatol. Palaeoecol. 136, 213-229.

Alexandre, A., Meunier, J.D., Mariotti, A., Soubies, F., 1999. Late Holocene phytoliths and carbon-isotope record from a latosol at Salitre, south-central Brazil. Quat. Res. 51 (2), 187-194.

Bartoli, F., Wilding, L.P., 1980. Dissolution of biogenic opal as a function of its physical and chemical properties. Soil Sci. Soc. Am. J. 44, 873-878.

Bremond, L., Alexandre, A., Hély, C., Guiot, J., 2005. A phytolith index as a proxy of tree cover density in tropical areas: calibration 
with Leaf Area Index along a forest-savanna transect in southern Cameroon. Glob. Planet. Change 45 (4), 277-293.

Delhon, C., Alexandre, A., Berger, J.P., Thiébault, S., Brochier, J.L., Meunier, J.D., 2003. Phytolith assemblages as a promising tool for reconstructing Mediterranean Holocene vegetation. Quat. Res. $59,48-60$.

Fredlund, G.G., Tieszen, L.L., 1994. Modern phytolith assemblages from the North American Great Plains. J. Biogeogr. 21, 321-335.

Fredlund, G.G., Tieszen, L.L., 1997. Phytolith and carbon isotope evidence for late Quaternary vegetation and climate change in the southern Black Hills, South Dakota. Quat. Res. 47, 206-217.

Kelly, E.F., 1999. Method for Extracting Opal Phytoliths from Soil and Plant Material. Intern. Rep, Dep. AgronColorado State Univ., Fort Collins, CO. $10 \mathrm{pp}$.

Kirman, S., Meunier, J.D., Alexandre, A., Varajao, A.F.D.C., Colin, F., 2002. The role of plants in the dynamics of iron crust formation at Uberaba, Minas Gerais, Brazil. 17th world Congress of Soil Science, Bangkok, Thailand, August 2002. Abstract, volume 1, p. 171

Kondo, R., Childs, C., Atkinson, I., 1994. Opal Phytoliths of New Zealand. Manaaki Whenua Press, Lincoln. 85 pp.

Madella, M., Alexandre, A., Ball, T., 2005. International Code for Phytolith Nomenclature 1.0. Ann. Bot. 96 (2), 253-260.

Mulholland, S.C., 1986. Classification of grass silica phytoliths. In: Rovner, I. (Ed.), Plant opal Phytoliths Analysis in Archeology and Paleoecology Proc. 1984, Phytolith Research Workshop. Phytolitharian Occasional Paper 1, Raleigh, NC, pp. 41-52.

Mulholland, S.C., 1989. Phytolith shape frequencies in North Dakota grasses: a comparison to general patterns. J. Archaeol. Sci. 16, $489-511$.
Mulholland, S.C., Rapp Jr., G., 1992. A morphological classification of grass silica bodies. In: Rapp, G., Mulholland, S.C. (Eds.), Phytolith Systematics, Emerg. Iss. Adv. Archaeol. Mus. Sci. vol. 1 , pp. $65-89$.

Piperno, D.R., 1988. Phytolith Analysis: An Archaeological and Geological Perspective. Academic Press, New York. 280 pp.

Piperno, D.R., Becker, P., 1996. Vegetational history of a site in the central Amazon Basin derived from phytolith and charcoal records from natural soils. Quat. Res. 45, 202-209.

Piperno, D.R., Jones, J.G., 2003. Paleoecological na archaeological implications of a Late Pleistocene/Early Holocene record of vegetation and climate from the pacific coastal plain of Panama. Quat. Res. 59 (1), 79-87.

Scurfield, G., Anderson, C.A., Segnit, E.R., 1974. Silica in woody stems. Aust. J. Bot. 22, 211-229.

Stromberg, C.A.E., 2004. Using phytolith assemblages to reconstruct the origin and spread of grass-dominated habitats in the great plains of North America during the late Eocene to early Miocene. Palaeogeogr. Palaeoclimatol. Palaeoecol. 207, 239-275.

Twiss, P.C., 1992. Predicted world distribution of $\mathrm{C}_{3}$ and $\mathrm{C}_{4}$ grass phytoliths. In: Rapp, G., Mulholland, S.C. (Eds.), Phytoliths Systematics Emerg, Iss. Adv. Archaeol. Mus. Sci., pp. 113-128.

Twiss, P.C., Suess, E., Smith, R.M., 1969. Morphological classification of grass phytoliths. Soil Sci. Soc. Am. J. 33, 109-115.

Wallis, L., 2003. An overview of leaf phytolith production patterns in selected northwest Australian flora. Rev. Palaeobot. Palynol. 125, $201-248$.

Wüst, R.A.J., Bustin, R.M., 2003. Opaline and A1-Si phytoliths from a tropical mire system of West Malaysia: abundance, habit, elemental composition, preservation and significance. Chem. Geol. 200, 267-292. 